P - 329 水溶液中における葆酸カルシウム 2 水化物結 晶の安定化 一ピロ裤酸ナトリゥムおよびクエン酸ナト リウムの効果（第 2 報）-

自治医科大学・湯澤政行・六塚一彦・徳江章彦

【目的】蓚酸力ルシウム 2 水化物 (COD)は尿路結石の一般的 な成分であるが、水溶液中では安定に存在せず、速やかに葆 酸カルシウム一水化物(COM)に変化してしまう。前回発表（第 81回総会）において水溶液中でのCODの安定化におよぼすピ ロ燐酸ナトリウム $\left(\mathrm{PP}_{\mathrm{i}}\right)$ とクエン酸ナトリウム(citrate)の影響を 報告した。今回、追加実験を行ったので前回のデータとあわ せて報告する。

【方法】PPおよびcitrateを含む蓚酸ナトリウム溶液に塩化力 ルシウム溶液を速やかに混合し産生された蓚酸カルシウム結 晶を粉末X線回折装置にて分析した。COM結晶とCOD結晶の 産生比に対するPP とcitrateの影響を調べた。更に産生された COD結晶の経時的変化についても検討した。

【結果】PPあるいはcitrateが存在すると優先的にCOD結晶が 形成され、しかも、PP およびcitrateの濃度によっては 上のCODが産生された。さらに産生されたCOD結晶は水溶 液中に長時間（7日以上）安定に存在した。PPir citrateの生 理的尿中濃度においてCODの安定化に対する相加的効果を認 めた。また、高いcitrate濃度において比較的大きなCOD結晶 が産生された。

【結論】水溶液中においてPPおよびcitrateはCOD結晶の安定 化効果を持つことが示された。

\section{$P-331$ 尿路結石中のニューキノロン分析について}

金沢医科大学

鈴木孝治・菅 幸大・森山 学・宮澤克人

【目的】ニューキノロン剤(NQ)は尿路感染症に広く使用され ているが、赤外分光分析法(IR法)では尿路結石中から微量成 分として発見されることがある。NQの測定法を検討すると ともに当科にて治療した尿路結石を対象にNQの含有につい て調査した。

【方法】1）当科でIR法にて分析した尿路結石1000個をNQ (TFLX, NFLX, OFLX)の標準波形と比較して調査した。2) 硫酸水素テトラブチルアンモニウム/アセトニトリルー燐酸カ リウム緩衝液を使用したHPLC法にてNQを測定した。3）結 石とNQを混和しIR法、HPLC法を用いて分析した。4）100 個の蓚酸カルシウム結石をHPLC法にてNQの含有を調査し た。

【結果】1)IR法では1000個の尿路結石中に2個の

NQ(TFLX)を含有する結石が発見された。2）IR法ではNQの うちTFLXのみが判明するが、HPLC法では他のNQも同時に 検出可能であった。3）100個のCaOx結石からは数個のNQ 含有が認められた。

【結論】NQ使用による治療上の安全性は確立されているが、 尿路結石中に微量ながら含有されること、時には結石を形成 する可能性があることが明かとなった。結石中に含まれる NQの分析法はIR法のみでは不十分でHPLC法を使用して解 析する必要がある。

\section{$P-330$ Struvite 結晶形成におけるmucinの影響}

堎隼義熟大学:

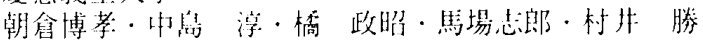

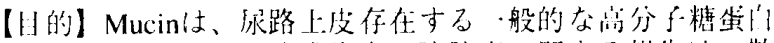
筫である。Mucinの㽷路感染症や膀脱癌に関寸る報售は、散 見されるが、㽷路結不に関しては少ない、Mucinは、in vitro modelで、シュウ酸カルシウム結晶の凝集を促准する上報篮 されているが(Grases, 1992)、struvite結晶形成については報管 き机ていない。そこで、本研究の目的は、mucinがin vitro model struvite formationにどのような影響を示すか検部与るこ とにある

【法】Struvite 結晶を発生させる力法は、Griftithなどの人

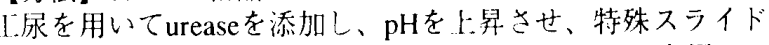
グラス上にstruvite crystalを発生させた。このモデルを䏳いて submaxillary gland mucin(type 1-S, M3895, Sigma)を添加 L、結 晶形態の違い、発生した結晶の最大径、結晶数を位相差顕微 鏡を用いて、直視下に観察し、mucinのstruvite formationに拉 ける影響を検討した。コントロールとしては、BSA(bovine serum albumin)を用いた。

【結果および結論】Mucinを加えることにより、発生する結 鼠の形態は、著しく变化した。すなわち、BSA添加例では、 典型的なX shaped crystalを示したが、mucin添加例では、直方 体に近い結晶となった。Mucin添加例は、BSA添加例に比較 して、結晶の最大径は、最大 $1 / 5$ に減少し、発生する結晶数 は、最大 2 倍に增加した。すなわち、傾向として、mucinを 加えることにより、結晶のサイズは小さくなる反面、発生結 晶数は多くなる傾向を示した。この結果は、in vitroの垁験絬 果ではあるが、臨床的にstruvite結石形成や結石予防を考える うえで、有効な情報となりうると考えた。

$\mathrm{P}-332$ ラット結石形成モデルにおけるアポトーシスおよび アポトーシス関連遺伝子の発現について

金沢医科大学

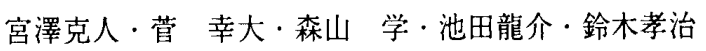

【目的】尿路結石形成機序における分子機構を観察する目的 で結石形成ラットでのアポトーシスおよびアポトーシス関連遺 伝子の関与について検討した。

【対象と方法】雄Wisterラットに0.5\%エチレングリコールの 自由飲水および $1 \alpha(\mathrm{OH}) \mathrm{D}_{3} 0.5 \mu \mathrm{g}$ 隔日強制投与で萑酸カルシ ウム結石を形成した。誘発 $1,3,5,7$ 日目、2,3,4週目、更に 誘発終了後1，2週目に腎を摘出した。TUNEL法によるDNA3' 末端標識抢よびDNAのagarose gel電気泳動法によるladder形 成の検出にてアポトーシスの観察、証明を行った。アポトーシ ス関連遺伝子産物であるp53ならびにbax遺伝子蛋白の発現を streptavidin-biotin complex法にて免疫組織化学的に検討し た。

【結果】TUNEL法ではコントロールおよび誘発1日目には全 く標識を認めず、誘発3日目より結晶沈着部位の尿細管上皮に 標識が出現し経時的に増加すると共に非結晶沈着部位へも拡がっ た。DNAの電気泳動法では $180 \mathrm{bps}$ 整数倍のladder形成が検 出された。免疫組織化学ではp53ならびにbax遺伝子蛋白とも にコントロールおよび結石形成ラットに発現を認めなかった。 